\title{
ARTIKEL
}

\section{STUDENTS' COMPETENCE IN PREDICTING INFORMATION THROUGH PICTURE ON READING TEXT AT GRADE VIII STUDENTS OF JUNIOR HIGH SCHOOL}

\author{
Disusun dan Diajukan oleh: \\ Putri Widya Ningsih \\ NIM. 2123121040
}

Telah diverifikasi dan dinyatakan memenuhi syarat

Untuk diunggah pada jurnal online

Medan, September 2016

\section{Menyetujui}

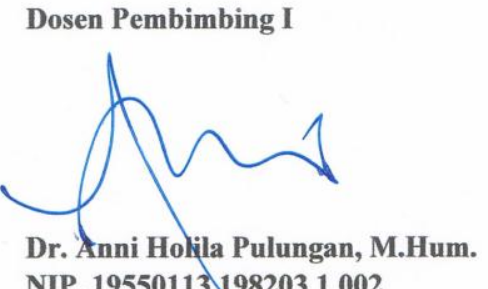

Dr. Anni Hokia Pulungan, M.Hum. NIP. 195501131982031002
Dosen Pembimbing II

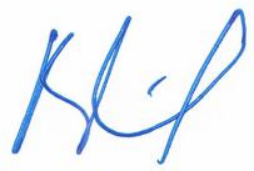

Rita Suswati, S.Pd, M.Hum NIP. 197704062008012019

Ka. Prodi Pendidikan Bahasa Inggris

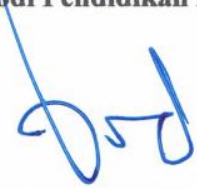

Nora Ronita Dewi, M.Hum NIP. 198005222008122003 


\title{
STUDENTS' COMPETENCE IN PREDICTING INFORMATION THROUGH PICTURE ON READING TEXT AT GRADE VIII STUDENTS OF JUNIOR HIGH SCHOOL
}

\author{
*Putri Widya Ningsih \\ ** Anni Holila Pulungan \\ ** Rita Suswati
}

\begin{abstract}
Ningsih, Putri Widya. 2123121040. Students' Competence in Predicting Information through Picture on Reading Text at Grade VIII Students of Junior High School. A Thesis. English Department. Faculty of Languages and Arts. State University of Medan. 2016.

This study is aimed to find out whether students pay more attention to picture, get information from picture and understanding the content of the text. It was conducted by using descriptive quantitative research. The source of the data was taken from the textbook entitled English in Focus published by Nur Ilmu, Yudhistira and students' grade VIII of SMPN 3 Percut Sei Tuan. There are 9 classes of grade VIII which consists of 325 students, and VIII-1 was taken as the sample of this research. The data of this study were obtained from the students' score of reading test. Based on the result of data analysis, it was found that the competence in predicting information through picture is very good. From 38 sample students, there were 21 students $(55,3 \%)$ got very good score or can predict more than 5 details of information from the text, 15 students $(39.5 \%)$ got good score or can predict less than 5 details of information from the text and only 2 students (5.2\%) got bad score or predict less than 2 information. As well as their reading comprehension of the text with mean score 82.37 which is higher than the Minimal Completeness Criteria (KKM) of reading applied by SMPN 3 Percut Sei Tuan. It can be concluded that The result of this research is appropriate to the theory which claim that pictures are useful for getting students to predict what is coming next in a lesson and help the students comprehend the text easily.
\end{abstract}

Keywords: Predicting Information, Picture, Reading Text. 


\section{INTRODUCTION}

\section{Background of the Study}

Reading as one of the four language skills is an essential skill for students and taught formally from elementary school up to the university level. It also has a great position in Learning English in the class, shown by the quantity of test that faced by the students in the National Examination in Indonesia which has included 15 listening and 35 reading questions based on Association of National Education Standard (BSNP).

Reading is a foundation skill for learning, personal growth, and enjoyment. Student must be able to read and understand text in all formats (e.g. picture, video, print). Nowadays there are many ways to get the information that students need by reading, such as from newspaper, magazine, novel, articles, journal and also other kind of reading book.

Though reading is supposed to be the most important skill, students often find difficulty to understand the new text without having prior knowledge because they are lack of vocabulary knowledge and they lack of a direct tool to help them in comprehending the text. Therefore, teacher should stimulate them to predict and infer what the text is about. The students need to know many words to get the information on the text. The teacher needs a strategy to make the students comprehend and catch the idea of the text easily. In this case, pictures can be used as a media to help the students awake their prior knowledge.

Picture is one of visual aids. It is one of the media that can help the students develop their knowledge about the topic of the text. Harmer (2007:179) affirms that pictures are useful for getting students to predict what is coming next in a lesson. When the students read certain text, they will easily get information when they understand the pictures. In 
addition, Schoches (2011:27) states that picture allows students to activate not only prior knowledge but also attitudes, beliefs, and misconceptions. Picture then creates a bridge between students' scheme (internal organization of concepts) and the newly introduced learning.

As a result, teacher should provide some pictures to facilitate the students in understanding the content of a text. Furthermore, proper pictures have to be considered because familiar and simple pictures are needed by the student.

Predicting by using picture is a strategy which has a high possibility in helping students' reading achievement. Through this strategy, students find clues or connecting points. All of our prior knowledge of places and situations enable us to predict when we read and thus to comprehend and enjoy what we read. Predicting brings potential meaning to text and reducing ambiguity (Moreillon, 2007:76). The predicting strategy activates students' prior knowledge and starts engagement with key concepts. It activates prior knowledge and shows students that they were smart enough to figure things out in reading.

But, the problem is how students could be able to recognize the information from the picture that is showed in reading text. Every student has their opinion to judge it, but they have to get the right point of information that would they find from the picture in reading text. Because usually, if they find some pictures in reading text, they just see at first glance, without realizing and recognizing what is the picture conveying. The students see the pictures in reading text as an entertainment for them. Actually they could get the information if they pay their attention toward the pictures in reading text. Therefore, they did not give full attention and enthusiasm in the process of reading. 
According to English syllabus of curriculum, one of the genres learned in Junior High School is descriptive text. Based on Dirgayasa (2012:3) descriptive text is a type of written text, which has the specific function to give description about an object (human or non-human or idea) vividly so that the reader can visualize the object described.

Based on the researchers' observation and interviewing the teacher in SMP Negeri 3 Percut Sei Tuan on grade VIII. The teacher told that her students have difficulty in understanding the content of a new text, as recently they learned descriptive. This situation is proven by the students' scores of reading. Most of students get the score below the Minimal Completeness Criteria (KKM) of SMPN 3 Percut Sei Tuan. The KKM of reading applied for grade VIII by school is 70 .

But when teacher used pictures as the tools in teaching reading descriptive texts, the students paid more attention to the pictures and when the teacher asked them to predict what will happen in the text, they have various answers. This situation motivates them to read and figure out the content of the text. The pictures also help the students in understanding new vocabulary in the text.

The study of analyzing the students' competence in predicting picture on the reading text has been done by some researchers. The finding of Thomas (2005) in her journal entitled "The Power of Prediction: Using Prediction to Increase Comprehension in Kindergarten" is that the children were motivated more and more each time the strategy was presented. It allows optimal participation from all members of the group and a constant flow of communication about the story. The outcome is that predicting plays upon the natural curiosity of children as motivator for reading. 
Campbell and Cuba (2015) investigated the importance of using picture in predicting in their journal entitled "Analysing the Role of Visual Cues in Developing Prediction- Making Skills of Third and Ninth Grade English Language Learners". The conclusion of this research is Visual Cues are useful tools in helping students to understand and comprehending the story.

Hence, based on the explanation above, the researcher is interested in conducting this research related to reading text which has pictures inside. The researcher will find out whether the students pay more attention to the pictures, whether they get the information easily from the pictures and understanding the content of the text.

\section{REVIEW OF LITERATURE}

Reading is one of four skills should be learned by learners of EFL/ESL. Though reading is very supposed to be the most important skill, the students of Junior High School are still hard to master it. This condition is caused by many factors such as the lack of students' interest to read the text, the lack of students' prior knowledge about the reading text and the ineffectiveness technique which was applied by the teacher. Therefore, students are difficult to get the message revealed by the writer which is conveyed in the text.

Predicting by using picture is a strategy which has a high possibility in helping students' reading achievement. Prediction is the prior elimination of unlikely alternatives. It is the core of reading. All of our prior knowledge of places and situations enable us to predict when we read and thus to comprehend and enjoy what we read. Predicting brings potential meaning to text and reducing ambiguity. The predicting strategy activates students' prior knowledge and starts engagement with key concepts. It 
activates prior knowledge and shows students that they were smart enough to figure things out in reading.

Students can be able to brainstorm how the information fits in with their previous knowledge. They learn to make connections between their own prior knowledge and the ideas in the text. It is helpful for students to see that sometimes their predictions were off and they have to stop think and might be revise their prediction. Predicting and revising also assist students in thinking while they read, they paid attention to see whether they right in their prediction or not. Giving the students time to revise their prediction support them to reread an important component of completely comprehension.

\section{RESEARCH METHODOLOGY AND FINDINGS}

\section{Methodology}

This research was conducted in a descriptive quantitative research. According to Kountur (2007:13) descriptive quantitative research is a kind of research that collects the information about the status of phenomenon at the time of conducting research and the collecting data are shown by numbers in order to obtain the percentage. It is a descriptive one because it is used to describe phenomenon such as ability, competence and level of achievement. Besides, this study was considered as quantitative because the result is described in frequencies, percentage and averages

In this study, test was used as the instrument of collecting the data. The researcher used pictures within a text to measure students' ability in predicting information through picture, in which the teacher asks students to predict the picture before they read the text and answer the questions to measure their reading comprehension. 
The data of this study are the result of the predicting information through picture test which was given by the teacher to students' grade VIII of SMPN 3 Percut Sei Tuan. The Source of data was taken from the textbook entitled English in Focus published by Nur Ilmu and students' grade VIII of SMPN 3 Percut Sei Tuan. There are 9 classes of grade VIII which consists of 325 students, and VIII-1 was taken as the sample of this research.

\section{Techniques of Analyzing the Data}

The data was analyzed through some steps using Ary et al. (2002:517) theory, as following:

1. Collecting the data

2. Checking and assessing students' answer

3. Calculating the Data

4. Put the data into table and percentage

5. Interpreting the results

\section{Findings}

The result of the data analysis showed that students' competence in predicting information through picture is very good. From 38 sample students, there were 21 students $(55,3 \%)$ got very good score or can predict more than 5 details of information from the text, 15 students $(39.5 \%)$ got good score or can predict less than 5 details of information from the text and only 2 students (5.2\%) got bad score or predict less than 2 information. 
The Essays score also showed that students' comprehension of the descriptive text is good. The total score was 3130 with mean score 82.37 which is higher than the Minimal Completeness Criteria (KKM) of reading applied by SMPN 3 Percut Sei Tuan.

The result of this research is appropriate to the theory which claim that pictures are useful for getting students to predict what is coming next in a lesson (Harmer, 2007:179) it is also help the students comprehend the text easily.

\section{CONCLUSION AND SUGGESTIONS}

\section{Conclusion}

In reference with analysing students' competence in predicting information through picture on reading text at junior high school, it could be concluded that students' competence in predicting information through picture on reading text at SMPN 3 Percut Sei Tuan is very good. From 38 sample students, there were 21 students $(55,3 \%)$ got very good score or can predict more than 5 details of information from the text, 15 students $(39.5 \%)$ got good score or can predict less than 5 details of information from the text and only 2 students (5.2\%) got bad score or predict less than 2 information.

Students' comprehension in reading descriptive text is good. The total score was 3130 with mean score 82.37 which is higher than the Minimal Completeness Criteria (KKM) of reading applied by SMPN 3 Percut Sei Tuan. With the highest score is 100 and the lowest score is 60 .

The result of this research is appropriate to the theory which claim that pictures are useful for getting students to predict what is coming next in a lesson (Harmer, 2007:179) it is also help the students comprehend the text easily. 


\section{Suggestions}

Since the result of students' competence in predicting information through picture on reading text at SMPN 3 Percut Sei Tuan is very good as well as their reading comprehension of the text, it is suggested that:

1. English teachers to use picture as their media in teaching reading to help the students develop their knowledge about the topic of the text.

2. The students to help their problem and their weakness in reading especially in comprehending a new text.

3. Other researchers to use this study as reference for further research.

\section{REFERENCES}

Ary, D. et al. 2002. Introduction to Research in Education. Wadsworth: Cengage Learning.

Campbell, E. and Cuba, M. 2015. Analyzing the Role of Visual Cues in Developing Prediction-Making Skills of Third and Ninth Grade English Language Learners. The CATESOL Journal. Vol. 27, No. 1

Dirgayasa, I. W. 2012. Maritime English. Medan: Unimed Press

Harmer, J. 2007. The Practice of English Language Teaching. $4^{\text {th }}$ Edition. Essex: Pearson Education Ltd.

Kountur, R. 2007. Metode Penelitian untuk Penulisan Skripsi dan Tesis. Jakarta: Buana Printing.

Moreillon, J. 2007. Collaborative Strategies for Teaching Reading Comprehension: Maximizing Your Impact. Chicago: American Library Association.

Schoch, K. 2011. Picture Books Across the Curriculum. [Online]. http://teachingreadingandla.pbworks.com/f/Picture\%20Books\%20Across $\% 20$ the $\%$ 20Curriculum\%202011\%20revised.pdf. (accessed on January $5^{\text {th }} 2015$ ) 
Thomas, U. 2005. The Power of Prediction: Using Prediction Journals to Increase Comprehension in Kindergarten. [Online]. http://files.eric.ed.gov /fulltext/ED490766.pdf (accessed on May $18^{\text {th }}$ 2016) 